\title{
8
}
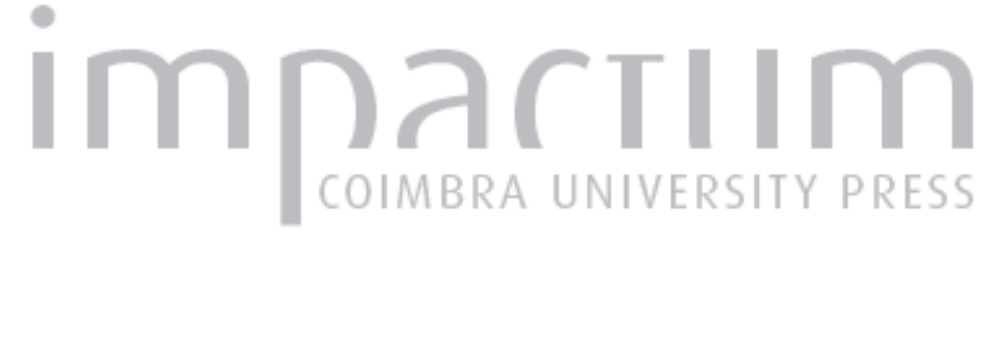

\section{Filosofia e Universidade em torno de um episódio da história da Filosofia na Faculdade de Letras de Coimbra)}

Autor(es): $\quad$ Carvalho, Mário Santiago de Publicado por: Faculdade de Letras da Universidade de Coimbra, Instituto de Estudos

URL

persistente:

DOI: DOI:http://dx.doi.org/10.14195/0872-0851_33_1

Accessed : $\quad$ 26-Apr-2023 13:34:49

A navegação consulta e descarregamento dos títulos inseridos nas Bibliotecas Digitais UC Digitalis, UC Pombalina e UC Impactum, pressupõem a aceitação plena e sem reservas dos Termos e Condições de Uso destas Bibliotecas Digitais, disponíveis em https://digitalis.uc.pt/pt-pt/termos.

Conforme exposto nos referidos Termos e Condições de Uso, o descarregamento de títulos de acesso restrito requer uma licença válida de autorização devendo o utilizador aceder ao(s) documento(s) a partir de um endereço de IP da instituição detentora da supramencionada licença.

Ao utilizador é apenas permitido o descarregamento para uso pessoal, pelo que o emprego do(s) título(s) descarregado(s) para outro fim, designadamente comercial, carece de autorização do respetivo autor ou editor da obra.

Na medida em que todas as obras da UC Digitalis se encontram protegidas pelo Código do Direito de Autor e Direitos Conexos e demais legislação aplicável, toda a cópia, parcial ou total, deste documento, nos casos em que é legalmente admitida, deverá conter ou fazer-se acompanhar por este aviso. 


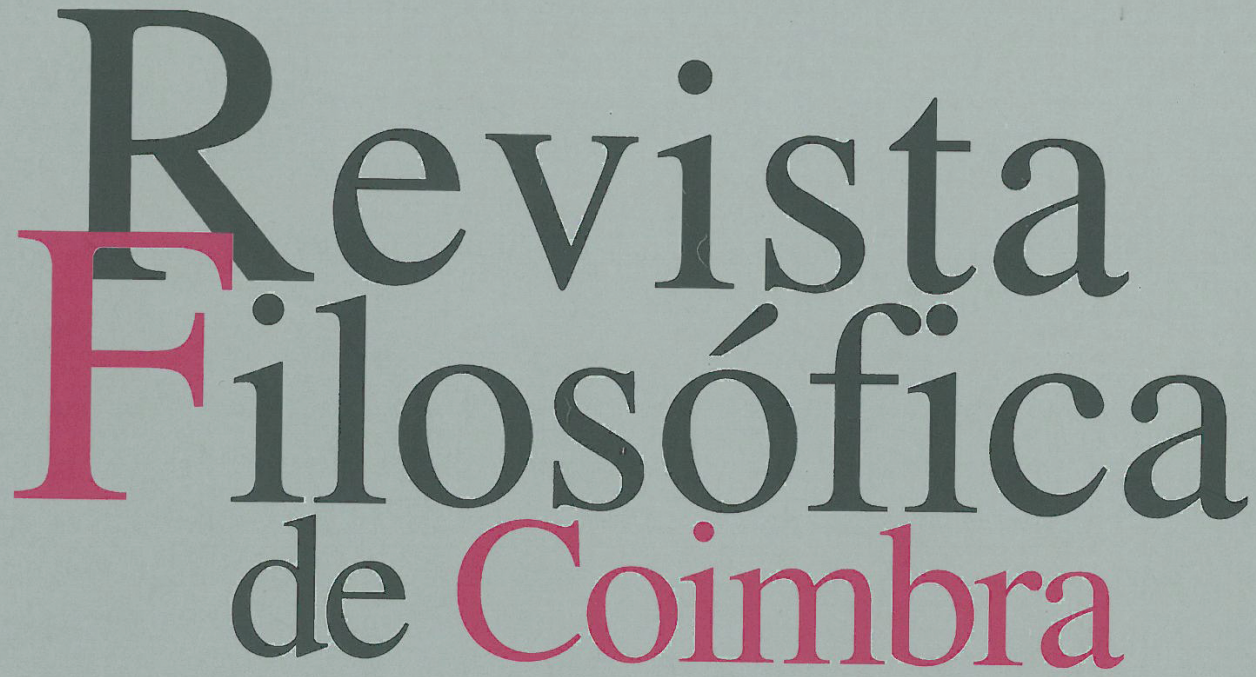

vol.17| n. .33 | 2008

Mário Santiago de Carvalho Fernanda Bernardo Luís António Umbelino Jean-Christophe Goddard Rui Alexandre Grácio Artur Ramos Luís M. Augusto Maria Luísa Portocarrero Jérôme Porée Diogo Ferrer Cláudio Alexandre Carvalho 


\section{FILOSOFIA E UNIVERSIDADE EM TORNO DE UM EPISÓDIO DA HISTÓRIA DA FILOSOFIA NA FACULDADE DE LETRAS DE COIMBRA IN MEMORIAM MICHAELIS B. PEREIRA \\ MÁRIO SANTIAGO DE CARVALHO \\ (Universidade de Coimbra)}

1.

A «natureza filosófica» opõe-se à mesquinhez. Afirmou-o Platão, referindo-se a essa natureza nos termos de «uma alma que pretende alcançar sempre a totalidade e a universalidade (tou holou kai pantós) do divino e do humano» ${ }^{1}$. Desprovida de mereologia, a parcialidade ou o encerramento num plano só exprime a viciosidade circular de uma sinédoque que, pelo frágil mas ágil golpe da paralaxe, frustra o mundo de uma ontologia que seja coerente com ele, isto é, ortogonal na sua expressão. A raiz da mesquinhez não é, por isso, deveras ética, antes ontológica e, no seu desvio figurativo, nessa dimensão estilística, exprime-se epistemologicamente. Quando noutra ocasião conjugámos a invocação «originária» da universitas com universum, reflectida a partir da palavra aristotélica da «alma que é de certo modo todas as coisas» ${ }^{2}$, no eco das palavras de Platão aplicadas à realidade universitária, críamos também haver lido ali um axioma da abertura enquanto Abertura, «posse desapossada que é a escuta do real em todas as suas manifestações». Não se compadecendo com o resultado aritmético do somatório das disciplinas ou (faculdades) leccionadas, mas remetendo para uma ideia reitora ou princípio «arquitectónico», uma tal abertura haveria de permitir a perscrutação do Uno e do Múltiplo, dos sendos com o ser, autenticamente habilitadora

\footnotetext{
${ }^{1}$ Platão, Rep. 486 a.

${ }^{2}$ Aristóteles, De An. III 8, 431b 21; vd. M.S.de Carvalho, A Síntese Frágil. Uma introdução à Filosofia (da Patrística aos Conimbricenses), Lisboa 2002, 24-26.
} 
da instauração do novum e propiciadora do acolhimento do outro. Quase nada na nova Universidade pragmática, tecnológica e empresarial que habitamos parece remeter para aquele momento originário. Pensa-se aqui, naturalmente, como J. Luís Aranguren, na «universidade tecnológica» organizada à maneira empresarial, «americana» ${ }^{3}$. Quer o estatuto privado e funcional da hiper-especialização, quer a pluriparcialidade epistemológica e a resposta pragmática de acrescentamentos departamentais ou mesmo cursos, colírios tópicos sem prévia reflexão sobre a essência, a natureza ou a ideia da Universidade, enquanto perfis contemporâneos de uma ciência em permanente pesquisa, perfilam-se hoje em dia, não obstante a lição singular de uma investigação sempre em aberto, como uma eventual «des-figuração» do que os sábios construtores medievais, coevos do aparecimento das Universidades em solo ocidental latino, chamaram a «uirga geometrica». Esta era, afinal, a régua de estimação em que se registava o logaritmo do novo espaço tutelar ${ }^{4}$. Porque aqui se tratará exclusivamente do curso de Filosofia, vale a pena deixar gravado, à guisa de egoísta exergo e póstuma homenagem ao seu autor, que o nosso eminente colega Miguel Baptista Pereira, qual arquitecto medieval ou inaugural, foi capaz de reinventar aquela «uirga geométrica» para justificar a existência do seu Instituto de Estudos Filosóficos, mediante palavras inspiradas, compostas para o Regulamento da Faculdade de Letras da Universidade de Coimbra: «Sentido humano do saber, do agir e do produzir, investigado na sua radicalidade». ${ }^{5}$

Manda o rigor da verdade histórica reconhecer-se que as Universidades, logo nos alvores das suas fundações ${ }^{6}$, nem sempre estiveram à altura deste horizonte de fulguração arquitectónica ideal. No momento em que se começava a esboçar a figura do «intelectual» universitário - projecto que haveria de estar ligado à reivindicação do estatuto da philosophia

${ }^{3}$ J. L. Aranguren, El futuro de la Universidad y otras polémicas, Madrid 1973, 78: «Llamo 'universidad tecnológica' a la organizada en forma estrictamente empresarial, como una enorme industria - 'industria de la educación' - para la 'fabricación' de esse saber tecnológico, inmediatamente aplicable, y de la correspondiente mano de obra - o manpower - que la sociedad industrial necesita perentoriamente, y a través de cuya formación (o deformación) integra en su seno.»

${ }^{4}$ Cf. M.S.de Carvalho, O problema da Habitação. Estudos de (História da) Filosofia, Lisboa Coimbra 2002, 12.

${ }^{5}$ Regulamento da Faculdade de Letras da Universidade de Coimbra, Coimbra 1997, 3 (os itálicos são nossos). Do mesmo autor, veja-se sobretudo «Universidade e Ciência» Revista da Universidade de Aveiro 1 (1984) 7-86; «Sobre o conceito heideggeriano de Universidade» Revista da Faculdade de Letras (Porto) 2a série: 14 (1997) 79-105.

${ }^{6}$ Cf. M.S.de Carvalho, O problema... 194. 
enquanto disciplina autónoma, reclame tornado possível pela recepção da maneira de um certo averroísmo ler o ideal peripatético da theoria ${ }^{7}$ - uma concepção da Faculdade de Teologia, mais como poder do que saber, ameaçava a autonomia já possível da filosofia e a sua liberdade de pensar. Quando o projecto da Teologia como ciência soçobrou, em seu lugar cresceu o modelo da Ciência - e depois o do Técnico-científico - que importa constante e vigilantemente desteologizar, sobretudo se, debaixo da sua graça, parece cair em desgraça a indagação e perscrutação das e nas Humanidades. Se adoptássemos o simplismo de uma linguagem positivista, poderíamos escrever que à Universidade teológica (medieval) sucedeu o estádio da Universidade metafísica (humboldtiana e napoleónica) onde com naturalidade acabou por se enxertar a Universidade técnico-científica (positiva) da qual emerge, agora, a Universidade pragmatista (empresarial). Nela reconhecer-se-á, no que nos diz respeito, a carência de uma investigação radical e integral do triângulo verbal e transitivo em que todo o humano se funda: saber, agir, produzir.

Dado que nenhuma ciência pode reflectir-se cientificamente no seu interior, esta tarefa deverá competir a uma instância externa, todavia fundacional como o quis ser a filosofia desde os seus iónicos alvores. Ainda é cedo para podermos ponderar se, no quanto nos diz respeito, os desafios de Bolonha agendam, sob o expressionismo pragmático da «integração europeia» - palavra-chave mais mágica e impensada do que reflectida -, um qualquer programa de desgraça, embora nos caiba a nós, seus mais ou menos protagonistas, cultivar a vigilância que o impeça. E, mais circunstancialmente, manda a vigil prudência do actualismo que, sem ecoarmos as vozes do velho do Restelo, saibamos reflectir em todo o capital de desafio e de tempestiva oportunidade (kairós) que comportam os avanços reformistas de um actual Governo da República. De nada nos serve, nem será porventura justo, culpar a esfera política do efeito bolonhês ou outro, e dos seus eventualmente deletérios objectivos - como o da (e de novo evoquemos outra palavra-mágica) empregabilidade - se, por falta de vontade e coragem, os universitários não cumprirem com a sua missão de vigilância permanente e esforço constante de renovação e resposta às cada vez mais rápidas transformações. Seja-nos permitido lembrar que foi assim que interpretámos um dos primeiros «intelectuais» pré-universitários ${ }^{8}$. A actual situação poder-se-ia traduzir, quiçá, na hipertrofia das escolas técnicas e «científicas», remetendo-se para o chão matricial das Humanidades - quando não o seu canto fúnebre - a repe-

\footnotetext{
${ }^{7}$ Vd. Id., ibidem... $193 \mathrm{sg}$.

${ }^{8}$ Vd. M.S. de Carvalho, Lógica e Paixão. Abelardo e os Universais, Coimbra 2001.
} 
tição, o ensino em segunda mão, o parasitismo manualista em prejuízo da investigação original e «radical» (no sentido etimológico e humano do adjectivo). É indiscutível que o programa de Bolonha é uma aplicação à pequeníssima e circunstancial escala geográfica europeia das consequências da democratização do ensino, também universitário. Dimensão indiscutivelmente positiva, de que sempre nos deveremos orgulhar, a sua faceta massificadora pode comportar riscos incalculáveis se lhe faltar uma perspectiva crítica, atenta e histórica. Ora, compete antes de mais às Faculdades de Letras - tenhamos presente que na semântica ocidental «littera gesta docet» - a comunicação crítica do e com o passado, isto é dizer, propiciar o advento do novo, autenticamente novo porque alicerçado no solo humano que é a sua condição. Em bom rigor, esta tarefa cabe a toda a Universidade enquanto Universidade, mas é imperativo justificar o papel e o horizonte «críticos» de uma «letra que ensina» o universo participial de «gero, geris»: o que se tem e se carrega consigo; o que se chama a si, seja para executar, seja para assumir o encargo; os gestos em que o Homem se supera - as façanhas ou proezas -, i.e., criando, produzindo e dando generosamente; o modo como se procede ou como responsavelmente nos comportamos; a própria passagem do tempo, nas suas flechas de herança com futuro, de presente responsabilizador e hospitaleiro, de futuro (telos) radicado no chão elementar (arché). Finalmente, para que da Universidade se possa repetir a palavra do Apocalipse $(21,7)$, «Faço novas todas as coisas» (kainà poiô pánta), não é tão imperioso o diagnóstico constante e reactivo (para não dizer corporativo) de uma ameaça, quanto a sabedoria propiciadora e participial da «gesta», tal como a acabámos de apresentar. E isto porque continua a ser verdade, como lamentava Baptista Pereira a propósito de um diagnóstico de um pensador que sempre meditou, Heidegger, sobre a «ameaça» resultante do primado do método e da técnica (Die Bedrohung der Wissenschaft), haver «biólogos que já não têm qualquer relação com 'a natureza viva num sentido essencial' nem dela necessitam das suas investigações», tal como «historiadores de arte sem uma relação verdadeira, experienciada e sofrida à história e à obra de arte». ${ }^{9}$

Apontámos noutra oportunidade um só momento da história da Universidade, chegando porém a confrontá-lo com um acontecimento posterior, atinente à vida do septuagenário Kant, com o seu quê de paralelo com a situação do século XIII ${ }^{10}$. Na linguagem kantiana estaria em causa a própria Razão (Vernunft), tal como no léxico de Boécio de Dácia

\footnotetext{
${ }^{9}$ M.B. Pereira, «Sobre o conceito...» 97.

${ }^{10}$ Cf. M.S.de Carvalho, O problema... 193-295.
} 
delinear-se-ia um programa de harmonização (reducere ad concordiam $)^{11}$ ou, igualmente, na terminologia epistémico-jurídica de Averróis, que servia de arrimo a este último, a problemática da relação (al-ittisal) ${ }^{12}$. Poder-se-ia, evidentemente, ir além do programa kantiano, evocando, desde o sentido enciclopédico ou sistemático de Fichte, até ao desafio de responder à crise hodierna que perpassa pela Universidade pós-massificadora, pós-metafísica, pós-positivista, pós-moderna, mas ainda ultra-especialista. Outros porém mais competentes o fizeram melhor do que nós o saberíamos fazer. Frisemos apenas aí a ideia, julgamos que capital, de que «só integrada no todo da existência humana pode a ciência exercer a sua função esclarecedora do agir livre do Homem e manter o seu carácter de mediação entre o cientista e a totalidade da vida e da sociedade humana.» ${ }^{13}$

Se nos ativemos ao acontecimento kantiano relativo à impossibilidade da unidade universitária no seio do conflito (Streit), e de novo o convocamos, é, porque, mais do que a afinidade com o acontecimento de 1277, agora, ele antecipa um dos motivos nucleares que estará em jogo no episódio universitário que nos propomos evocar nesta instância, o princípio da autonomia intelectual perante a intromissão política do Estado. O segundo motivo será já atinente a duas distintas concepções do trabalho-filosófico universitário e, por isso, não carente de significado na história da filosofia do nosso país, haja em vista que nele intervieram, embora de maneiras muito diferentes, duas das mais importantes figuras dessa história, no século XX, o filósofo do Porto Leonardo Coimbra (1883-1936) e o professor de Coimbra Joaquim de Carvalho (1892-1958). Aclaremos imediatamente haver uma acepção negativa do princípio de autonomia, sempre que ele for entendido de maneira neutra, superficial, digamos mesmo preguiçosa, como a atitude de indiferença do 'vale tudo' que recalca a dificuldade do pensar comprometido e vinculado ao que importa pensar. Adicionemos, depois, que o confronto das duas posições filosóficas se prende também a uma certa ideia de Universidade e do modo do seu trabalho, justificando-se assim a intersecção exposta pelo título da presente e despretensiosa evocação. Das três dimensões do «problema universitário», tal como o caracterizou

${ }^{11}$ Cf. Boécio de Dácia. A Eternidade do Mundo. Trad., introd. e notas de M.S. de Carvalho, Lisboa 1996, 33.

${ }^{12}$ Cf. Averróis. Discurso Decisivo sobre a Harmonia entre a Religião e a Filosofia. Trad,, introd. e notas de C. Belo, Lisboa 2006, 53; sobre o termo árabe, vd. o nosso Falsafa. Breve introdução à Filosofia arábico-islâmica, Coimbra 2006, s.v., e também 129 e passim.

${ }^{13}$ Vd. M.B. Pereira, «Universidade...» 82, com ampla bibliografia sobre o tema. 
J. Luís Aranguren - técnica ${ }^{14}$, social ${ }^{15}$ e política ${ }^{16}$ - no contexto episódico que aqui nos traz, nem todos têm um peso equivalente.

Contextualizemos, primeiro, apesar de modo rápido, a situação na origem de Der Streit der Fakultäten (1794) ${ }^{17}$ : no pressuposto pragmático de que a Sociedade necessita de orientações e o Estado tem a obrigação de favorecer a resolução de questões práticas - o que faz mediante o funcionalismo (pastores eclesiásticos, agentes da medicina e administradores da justiça) -, resulta a competência do Estado para se pronunciar e aprovar os programas - a «exposição pública» - das Faculdades ditas superiores (esta hierarquia exprime primordialmente uma divisão política e não científica). Antes mesmo de continuarmos, apontemos o efeito pragmático - e hoje em dia cada vez mais bem conhecido - da submissão da esfera epistémica à profissional, como se o saber, o agir e o produzir apenas devessem acompanhar a oferta de um trabalho - a impensada empregabilidade - que deixou de se ver mergulhado no vasto solo da terra humana. Eis, evidentemente, uma dimensão que será mais própria da universidade napoleónica (1806) do que da humboldtiana (1810), esta singularmente menos sensível à vinculação sócio-política em nome de uma concepção idealista do saber ou de uma estreita unidade entre investigação e ensino ${ }^{18}$. Mas Kant continuava, ainda antes desses dois paradigmas: o quadro hierárquico que exige uma Faculdade inferior radica, afinal, na própria natureza humana (ist die Ursache in der Natur des Menschen anzutreffen), pois se o estatuto dessa Faculdade - distintamente das superiores - é o gozo da liberdade, «quem pode mandar embora seja um humilde servo de outrem, imagina-se superior a outro que é, sem dúvida, livre, mas a ninguém tem de dar ordens» ${ }^{19}$. Sendo a razão «o poder de julgar com autonomia, i.e., livremente (segundo os princípios do pensar

${ }^{14}$ J. L. Aranguren, El futuro... 46-54: insuficiência quantitativa do pessoal docente; remuneração escassa e, por isso, deficiente dedicação; ausência de exigência; insuficiências materiais das instalações e meios.

15 J. L. Aranguren, El futuro... 54-59: deficiente resposta à massificação/democratização da educação; selecção classista encapotada; deficiente assistência da sociedade à universidade; monolitismo universitário frente ao pluralismo da sociedade.

16 J. L. Aranguren, El futuro... 59-61: despolitização em nome de um ensino/ /aprendizagem não político.

${ }^{17}$ I. Kant, Der Streit der Fakultäten in drei Abschnitten, in Id., Kleinere Schriften zur Logik und Metaphysik, hrsg. K. Vorländer, Leipzig 1905; Id., O Conflito das Faculdades. Trad. A. Morão, Lisboa 1993.

${ }^{18}$ Cf. P. Ferrer Pi, La Universidad a examen, Barcelona 1973, 19-20.

${ }^{19}$ I. Kant, Der Streit... 58 (trad.: 22). 
em geral)» deve conceber-se a Faculdade de Filosofia como responsável «pela verdade das doutrinas que tem de acolher ou até só admitir», «livre e unicamente dependente da legislação da razão» e não da do Governo, podendo, além do mais, submeter «todas as disciplinas ao exame da sua verdade ${ }^{20}$. Poderíamos, segundo Kant, apontar dois tipos de conflitos, um explicado pela atitude de cada Faculdade Superior contrariar a sua finalidade - como quando quer promover a influência dos seus diplomados sobre o povo que reclama os seus poderes mágicos - o outro - o conflito legal - que resulta do facto de os conteúdos doutrinais ordenados pelo Estado poderem colidir com as doutrinas da razão, que a Faculdade de Filosofia deve salvaguardar através da «plena liberdade de um exame público» ${ }^{21}$. Kant assegura, julgamos que sensata ou até mesmo sabiamente, tratar-se de um conflito irresolúvel de forma amigável (amicabilis compositio), que ele jamais cessará - facto para o qual a Faculdade de Filosofia deve estar sempre armada, sem depor as suas armas frente ao perigo que a ameaça, já que as Faculdades superiores não renunciam nunca ao desejo de governar - resultando daqui uma permanente situação conflitual de oposição de propósitos finais, uma concordia discors, discordia concors nas expressões latinas do filósofo alemão.

Como dissemos, a partir de 1800 as duas tendências contraditórias mas decisivas e comuns à Universidade do século XIX (que deste ponto de vista termina só em 194522) - o modelo napoleónico (sistema organizado central e governamentalmente que visa a imediata utilidade social) e o de humboldtiano (investigação sem objectivos práticos destinada a servir a educação intelectual da raça humana) - passaram a organizar o mundo universitário, pelo menos o europeu, sendo no vórtice das suas clivagens e mestiçagens que o conflito que vivemos hoje se estende ao campo dos «papéis sociais» das Universidades. Numa obra muito conhecida com o seu quê de oportuno, W. Ruegg resumia esse campo da seguinte maneira: «Os valores e as normas fundamentais que obrigam os seus membros

${ }^{20}$ I. Kant, Der Streit... 66-68: «Nun nennt man das Vermögen, nach der Autonomie, d.i. frei (Prinzipien dês Denkens überhaupt gemäss) zu urteilen, die Vernunft. Also wird die philosophische Fakultät darum, weil sie für die Wharheit der Lehren, die sie aufnehemen oder auch nur einräumen soll, stehen muss, insofern als frei und nur unter der Gesetzgebung der Vernunft, nicht der Regiereung stehend gedacht werden müssen. (...) Die philosophische Fakultät kann alle Leheren in Anspruch nehmen, um ihre Wahrheit der Prüfung zu unterwerfen.» (trad.: 31-32).

${ }^{21}$ I. Kant, Der Streit... 72 (trad: 37).

${ }^{22}$ W. Rüegg, «Prólogo», in AA.VV., Uma História da Universidade na Europa. Vol. 1: As Universidades na Idade Média, Lisboa 1996, xxii. 
[sc.: da Universidade] não são homogéneos. Os valores da validade universal dos critérios, métodos e resultados da investigação científica e académica não podem ser sempre aceites em consequência das limitações a que estão sujeitos e da diversidade dos poderes cognitivos dos seres humanos individuais. A igualdade de oportunidade de admissão e de continuação de estudos nas universidades entra em conflito com a desigualdade existente na distribuição dos recursos sociais e económicos e com as alternativas de utilização desses recursos. A prioridade dada ao lazer e à contemplação, que são necessários para a investigação científica e académica, representa um ideal do 'bios theoretikos', que, desde os filósofos gregos, tem estado em permanente contraste e em conflito com o ideal do 'bios praktikos', que dá prioridade à utilidade social da aplicação do saber científico e da preparação para as profissões, ambas oferecidas pelas universidades. O 'amor sciendi', que valoriza grandemente a procura da verdade através de métodos científicos e académicos rigorosos, anda associado à indiferença quanto ao valor económico dos resultados da investigação e do ensino e entra em contradição com a 'ambitio dignitatis' e a 'individia pecunie', a utilização social e económica dos frutos do estudo económico. Em último lugar, mas igualmente importante, o valor fundamental da liberdade académica da universidade, como comunidade corporativa, está em conflito potencial com duas frentes: internamente, entre a liberdade do indivíduo e a solidariedade colegial dos membros da universidade; e, externamente, entre os requisitos de autonomia por parte da universidade e o controlo por parte daqueles que lhe concedem os recursos financeiros necessários.» ${ }^{23}$

Devidamente deslocado ou adaptado, a perenidade do conflito paradigmaticamente analisado por Kant manifesta-nos uma Universidade sempre em crise, não obstante a procissão dos programas unificadores e sistematizadores a que ela vem assistindo, pelo que resultará fecunda a aceitação do convívio permanente com a pluralidade - digamos que hoje em dia esta apenas é mais explícita - enquanto regra reitora de uma Universidade enquanto Universidade, i.e., empenhada na criação plural, no diálogo vigilante às imposições e sensível às diferenças, de uma Universidade - repetimo-nos - que haja de permitir a perscrutação do Uno e do Múltiplo, dos sendos com o ser, autenticamente habilitadora da instauração do novum e propiciadora do acolhimento hospitaleiro do outro.

${ }^{23}$ W. Rüegg, «Prólogo» xxiv. 
2.

Vêm estas notas preambulares e esparsas a propósito, como dissemos, de um acontecimento ligado à história da filosofia portuguesa - tomamos este adjectivo como um termo geográfico neutro, quer dizer, alheio à «especulação» de Álvaro Ribeiro motivado por Sampaio Bruno ${ }^{24}$ - em que a Faculdade de Letras da Universidade de Coimbra se viu envolvida. Trata-se, aliás, de um momento que não costuma ser habitualmente convocado pela historiografia especificamente filosófica. A permissão é justificável, mas, enquanto episódio (que obrigatoriamente aqui se apresentará), ele concita-nos a uma ponderação quiçá tempestiva porque universal ou menos episódica. Referimo-nos, como é óbvio, à breve desanexação da Faculdade de Letras, da responsabilidade do célebre filósofo portuense Leonardo Coimbra, e em que o Grupo de Filosofia da mesma Faculdade, mormente o seu pequeno corpo docente se viu, ao que parece involuntariamente, como protagonista.

Não é difícil contextualizar essa nova (essa outra) questão coimbrã. Pelo decreto 5770 (de 10 de Maio de 1919), Leonardo Coimbra, na altura Ministro da Instrução, a Faculdade de Letras, apenas oito anos volvidos sobre a sua criação, era desanexada da Universidade de Coimbra e colocada na Universidade do Porto. Logo de seguida, o mesmo ministro decretava a nomeação de Newton de Macedo (1894-1944) e de Lúcio Alberto Pinheiro dos Santos (1889-1950) para professores ordinários do Grupo de Filosofia da Faculdade de Letras de Coimbra ${ }^{25}$. Entre os vários considerandos avocados pelo decreto para a transferência da Faculdade conimbricense para a cidade invicta que acolherá a Faculdade de Letras que mais tarde irá ter L. Coimbra como Director ${ }^{26}$, é legítimo invocar

${ }^{24}$ Cf. A. Ribeiro, O problema da filosofia portuguesa, Lisboa 1943.

${ }^{25} \mathrm{Vd}$. o texto do Decreto de nomeação in A Faculdade de Letras da Universidade de Coimbra ao País, Coimbra 1919, (31).

${ }^{26}$ M. Spinelli, A Filosofia de Leonardo Coimbra. O Homem e a Vida, dois termos da sua Antropologia Filosófica, Braga 1981, 20-21. J. F. Gomes anota ainda (A Universidade de Coimbra durante a primeira República (1910-1926), Lisboa 1990, 331), acerca de L. Coimbra: «... recorde-se que, em Dezembro de 1912, e em Janeiro de 1913, fizera concurso de provas públicas para assistente do $6^{\circ}$ grupo (Filosofia) da Faculdade de Letras de Lisboa. Com ele, concorreram António Sérgio de Sousa e João António de Matos Romão, tendo este último sido aprovado em mérito absoluto. Leonardo Coimbra ficou marcado por este desaire e teria jurado a si mesmo ser professor universitário, ainda que, para isso, tivesse de criar uma Faculdade... Nomeado Ministro da Instrução, transformou o sonho em realidade.» Recorde-se que L. Coimbra foi Ministro da Educação por duas vezes, a primeira das quais - a que nos interessa aqui - decorreu entre 2 de Abril e 28 de Junho. Sobre Matos 
temática para-filosófica. Esta decorria de um diagnóstico que está longe de ser sereno. Seria o caso da alegada preferência da «erudição livresca sobre as especulações originais do espírito moderno», patenteada «numa quase completa orientação tomista de forma escolástica» dos professores coimbrões ${ }^{27}$. Melhor ainda: «o professorado e o corpo docente da Universidade» de Coimbra - lia-se alfim - vivia «como que insulado no seu trabalho especulativo, literário ou científico». Na letra do Ministro que previamente havia escrito obras filosóficas inteligentes e deveras representativas - O Criacionismo. Esboço de um Sistema Filosófico (1912), A Morte (1913), O Pensamento Criacionista (1914), A Alegria, a Dor e a Graça (1916), e A Luta pela Imortalidade (1918) -, bastavam porém três notas só para caracterizar o horizonte mental da Faculdade de Letras de Coimbra (e mormente da sua secção de Filosofia): isolamento intelectual, eruditismo livresco, escolasticismo tomista.

Seja-nos permitida uma breve retrospectiva de enquadramento. Chamado, por impedimento de Carolina Michaëlis de Vasconcelos, a pronunciar a lição inaugural do ano académico 1912-13, o professor António de Vasconcelos, que transitara da Faculdade de Teologia para a recém-fundada Faculdade de Letras, elegia, justificadamente, como tema da sua oração, as Faculdades de Letras ${ }^{28}$. Começando por evocar os tempos em que a Faculdade se encontrava instalada nos colégios de S. Miguel e de Todos os Santos na rua da Sofia, i.e., os tempos áureos da velha Universidade, no século XVI, e historiando de seguida a sua decadência até à intervenção reformista do Marquês de Pombal - que criara, sob os modelo das suas congéneres alemãs, uma Faculdade de Filosofia em quatro secções - o ilustre professor fazia contrastar a quase imediata amputação da primeira secção (a de Filosofia racional e moral), com a coragem do Governo provisório da novel República que em 19 de Abril de 1911 instituía a Faculdade de Letras na Universidade de Coimbra (e no mesmo acto as Universidades de Lisboa e do Porto, aquela também dotada de uma Faculdade de Letras). Antes de fundamentar geográfica ou geopoliticamente a criação governativa, recenseando as Faculdades de

Romão, vd. o desabafo de Vieira de Almeida a Joaquim de Carvalho, com data de 1953 embora, in A.J.F. de Oliveira, Cartas de Edmundo Curvelo a Joaquim de Carvalho (1947-1953) e outros inéditos, Lisboa 2005, 146.

27 Vd. o texto do Decreto in J. de Carvalho, A Minha Resposta, Coimbra 1919, 17.

28 A. de Vasconcelos, Faculdades de Letras. Lição inaugural do Ano Lectivo de 1912- 1913 Na sessão solene de abertura da Universidade de Coimbra a 15 de Outubro, Coimbra -1912 (agora in F. de Oliveira (coord.), Orações de Sapiência da Faculdade de Letras 1912-1995), Coimbra 2002, 19-46). 
Letras ou afins que existiam na Europa de então - de Espanha à Turquia, sem excluir os países eslavos - António de Vasconcelos justificará de passagem o «campo de actividade científica» de uma Faculdade de Letras. Situar-se-ia ele no âmbito do estudo do «Homem considerado ser psicológico e social» - «0 zoon psychikón kai politikón dos gregos», anota esclarecendo que, no quadro dos seus três grupos de ciências - psicológicas, históricas e filológicas - nas primeiras, as que aqui nos interessarão, «a Faculdade de Letras estuda o homem em si mesmo, faz incidir a análise e a crítica racional sobre o seu próprio ser, ensina-o a perscrutar o que há de mais íntimo e mais difícil de atingir no fundo da sua consciência, os seus pensamentos e sentimentos, os motivos e o mecanismo dos seus actos...» 29

Em teoria, portanto, quer António de Vasconcelos, quer o legislador republicano, cada um à sua maneira, conceberam o ensino das Humanidades, e da Filosofia em particular, sem saberem (ou poderem) romper com a dimensão mais científica ou positivista do ideário das Luzes acolhido desde 1772, nos Estatutos da Universidade de Coimbra (Liv. III, Parte III). Este previa para o «Curso Filosófico» as quatro disciplinas seguintes Filosofia Racional e Moral, História Natural, Física Experimental e Química Teórica e Prática (vd. Apêndice I). Seria evidentemente estultícia confundir o plano do século XVIII com aquele que vê nascer a Faculdade de Letras e, nela, o seu Curso de Filosofia. Nomes como os de Consiglieri Pedroso, Teófilo Braga, Adolfo Coelho ou Silva Cordeiro haviam insistido na necessidade de reformar os Cursos de Letras, sendo clara a insatisfação com os decretos de 24 de Dezembro de 1901 e de 3 de Outubro de 1902. De facto, quando fora criado o Curso Superior de Letras, por D. Pedro V, em 1858, procurara-se timidamente colmatar um panorama filosófico interrompido havia mais de meio século na Universidade quando esta viu suprimido o curso de Filosofia Moral e Racional (Carta régia de Janeiro de 1791), conforme sublinhava A. de Vasconcelos, na alocução inaugural, pelo «costume de não se realizar um aperfeiçoamento no ensino senão mediante a condição expressa de não se aumentar um ceitil à despesa» ${ }^{30}$. Timidamente, dissemos, posto que, nas palavras de um competente especialista dos nossos dias, se «o panorama do cultivo da Filosofia, ao longo do século XIX, não deixa de ser

${ }^{29}$ A. de Vasconcelos, Faculdades... 13.

${ }^{30}$ A. de Vasconcelos, Faculdades... 10. Tratou-se, no caso, de destacar o ensino da Botânica e da Agricultura, da cadeira única de História Natural, para o que, por razões de economia, lembra ainda o autor, se suprimiu «a cadeira única que na Faculdade representava a secção humanística da Filosofia!» 
sombrio» ${ }^{31}$, o cenário que se abriu nem sempre viu iluminarem-se as luzes da ribalta. Aparentemente, por isso, «a criação das duas Faculdades de Letras, em Coimbra e em Lisboa, representava uma verdadeira integração de Portugal na cultura superior literária dominante em todos os países de alta civilização» ${ }^{32}$.

\subsection{Leonardo Coimbra e a ideia de Universidade}

Leonardo Coimbra - em cujo Criacionismo Teixeira de Pascoaes, vira (e citámo-lo à guisa de inquietante paradoxo) «a aurora de um pensamento português» num génio, como o lusíada, que tem «um verdadeiro horror à filosofia» ${ }^{33}$ - expôs a sua perspectiva final sobre a querela que ora nos ocupa em A Questão Universitária (1919) ${ }^{34}$. Teremos no entanto de dizer que esse escrito não é o mais feliz de ponto de vista filosófico, sobre a presente matéria.

Antes da publicação do famigerado decreto, em 27 de Abril, numa entrevista a $O$ Mundo, já na qualidade de Ministro da Instrução, L. Coimbra tivera a oportunidade de expender o que poderia ser o princípio norteador de uma reforma universitária, nos termos seguintes: «... aproveitados os magníficos elementos nacionais, chamaria verdadeiros criadores da ciência que, em torno de si, formariam núcleos de aperfeiçoamento, dando à vida universitária a fecundidade científica que lhe compete. (...) Das coisas da minha especial competência antecipadamente vou tratando; e assim, já reformei o curso de filosofia, de molde a actividade filosófica ser alguma coisa de sério em Portugal. Embora haja prevenções justificadas pelo mau passado duma causa a que impropriamente se chamava filosofia, essa actividade de pensamento é a imediatamente anterior e determinante da actividade técnica social.» $\mathrm{Na}$ mesma ocasião, misturava um novo motivo, nitidamente político, no rescaldo do pós-guerra, para o seu iminente despacho de desanexação: «Reconheço na Universidade portuguesa competências que altamente honram o país. No entanto, devemos ter a coragem de afirmar que essa Universidade, no seu conjunto, não é, como devia ser, a parte mais lúcida e nobre da consciência nacional! Basta reparar na sua atitude perante a

${ }^{31}$ F. da G. Caeiro, «Miranda Barbosa e a Filosofia em Portugal» Biblos 62 (1986) 2.

32 A. Ferrão, «O Prof. Joaquim de Carvalho e a sua época» Miscelânea de Estudos a Joaquim de Carvalho 3 (1960) 219.

33 T. de Pascoaes, Arte de Ser Português, Lisboa 1978 (reprod. da 2a ed.: 1920).

${ }^{34}$ L. Coimbra, A Questão Universitária (Discurso Parlamentar), in Obras de Leonardo Coimbra I, selec., coord. e revisão de S. Dionísio, Porto 1983, 605-27. 
guerra europeia que foi, incontestavelmente, o facto mais notável da nossa história moderna. A sua atitude colectiva foi de indiferença. E se os elementos da Universidade tiveram a consciência do momento, outros, e em maior número, foram francamente propagandistas duma neutralidade impossível e, até, de puro germanofilismo.» ${ }^{35}$ Leiam-se depois as palavras do mesmo ministro-filósofo, na Câmara dos Deputados, em 24 de Junho: «De forma que, se eu quisesse falar da rebeldia da Faculdade de Letras, teria apresentado à Câmara documentos que possuo, como telegramas em cifra, mandados daqui para Coimbra e que a polícia nos vinha trazer. Eu quis pôr a questão no pé que ela devia ser posta. É que há professores da velha faculdade de Teologia, e que fazem parte da Faculdade de Letras, que, pela sua formação psíquica, como disse o Sr. Alves dos Santos encontrando-se dentro de confissões religiosas, não podem oferecer, para um dado ensino, as garantias de neutralidade e imparcialidade que esse ensino requer. (...) ${ }^{36}$. Tirante estes motivos políticos - mas a eles ainda voltaremos - sublinhemos o indiscutível desiderato de uma «fecundidade científica» na «actividade filosófica», que se deve tornar «alguma coisa de sério em Portugal», e o princípio da imediata «anterioridade» e «determinação» dessa actividade em relação às componentes técnica e social. Seria, pois, injusto, como veremos, não se reconhecer na ingerência da desanexação a marca ou o efeito de uma qualquer reflexão ainda filosófica.

Vários intérpretes se têm pronunciado sobre o horizonte dessa intervenção leonardina, sobressaindo porém a justificação antipositivista. António Quadros, por exemplo, escreve que tal reforma da Universidade obedeceu a «uma orientação antipositivista» ${ }^{37}$ e pelo mesmo tom afinava Orlando Vitorino ampliando todavia a justificação da extinção para uma genealogia que radicava na universidade pombalina - paradoxalmente L. Coimbra apelidava-a antes de «universidade jesuítica»-, nos termos seguintes: «Ao fazer o que fez - transferência para o Porto da Faculdade de Letras, de Coimbra - Leonardo não iludiu contudo a astúcia dos universitários que contra ele lançaram a mais insidiosa campanha política de que há memória mas não história (...) As dimensões desta campanha - em que participou, seu primeiro acto público, Oliveira Salazar - só se explicam pelo facto de os universitários não se terem iludido. O que estava

${ }^{35}$ Cf. L. Coimbra,Cartas, Conferências, Discursos, Entrevistas. Compilação e notas de P. Gomes e P. Samuel, Lisboa 1994, 74-75 (O Mundo, ano XVIII, nº 6532).

${ }^{36}$ L. Coimbra, Cartas... 78.

${ }^{37}$ A. Quadros, «A Obra de Leonardo Coimbra no contexto cultural da sua época» in AA. VV., Leonardo Coimbra. Filósofo do Real e do Ideal (Colectânea de Estudos), Lisboa $1985,23$. 
em jogo não era a simples transferência de uma escola. Era a existência e o modelo de uma universidade pombalina. E estava em causa na Faculdade que, então como hoje, é aquele de que mais depende todo o ensino e a formação mental das gerações: a Faculdade de Letras.» ${ }^{38}$. Talvez antecipando, à sua maneira, o que P. Bourdieu irá chamar a «reprodução do corpo universitário» detentor de uma «autoridade estatutária» ${ }^{39}$, Álvaro Ribeiro ponderava que «... o que houve de sério (...) na significativa questão universitária, foi o protesto da Universidade de Coimbra contra mais um acto de quebra de uma tradição venerável. Efectivamente, assim como a tradição apostólica é garante da hierarquia eclesiástica, também a hierarquia universitária não pode ser adulterada por um acto simples do legislador. (...)»E Ribeiro concluía, num tom de também profética actualidade: "Atribuímos à Universidade de Coimbra a responsabilidade da profanação progressiva que viria a permitir a constituição de faculdades universitárias pelo processo leigo de fabricar escolas técnicas...» ${ }^{40}$ Posto que de maneira menos conseguida, apesar de afinada pelas próprias palavras de Leonardo, J. Domingues explicava a interferência pela «formação psíquica» dos professores da Faculdade de Letras provenientes da antiga e extinta Faculdade de Teologia, justificada pela experiência infeliz e negativa da formação escolar do filósofo portuense ${ }^{41}$. Semelhante explicação psicologizante estaria, contudo, em oposição com a «coerência» e a «solidariedade intrínseca», com a globalidade de um pensamento exarado n'A Questão Universitária ${ }^{42}$. Num relato escrito muitos anos depois do bizarro evento, um dos bons conhecedores dos meandros desse episódio, António Ferrão, contextualizava outras razões. Primeiro, a Universidade de Coimbra, suspeita de convicções políticas monárquicas, tinha sido alvo de inquérito - concluído em 26 de Abril de 1919 - que acabou embora por nada apurar em relação a suspeitas anti-republicanas por parte de alguns docentes ${ }^{43}$. Por outro lado, o ministro L. Coimbra, «publicista

38 O. Vitorino, «Leonardo e a Política» in AA. VV., Leonardo... 236.

${ }^{39}$ P. Bourdieu, Homo Academicus, Paris 1984, 112.

${ }^{40}$ A. Ribeiro, «Leonardo Coimbra e a política do seu tempo» in AA.VV., Leonardo Coimbra. Testemunhos dos seus contemporâneos, Porto 1950, 145-46.

${ }^{41}$ J. Domingues, «Leonardo Coimbra, educador» in Id., De Ourique ao Quinto Império. Para uma filosofia da cultura portuguesa, Lisboa 2002, 165.

42 J.F.da G. Caeiro, Dispersos II. Org. de MadeL. S. Ganho, Lisboa 1999, 74; vd. ainda P. Calafate, «Filosofia da Educação e Reforma do Ensino na Obra de Leonardo Coimbra», in ID., Metamorfoses da Palavra. Estudos sobre o pensamento português e brasileiro, Lisboa 1998, 259-266 (com referências e enquadramento).

${ }^{43}$ A. Ferrão, «O Prof. Joaquim de Carvalho...» 223. 
imaginoso, escritor de grande poder verbal, mas oco» ter-se-ia facilmente deixado influenciar ${ }^{44}$. Também Henrique Barrilaro Ruas, explicitava mais razões, nomeadamente a influência das «teses concretas» do Partido Democrático no novel ministro: «Para a mentalidade igualitária e jacobina vigente em quase toda a I República, a Coimbra universitária era o derradeiro vestígio da Idade Média: basta lembrar que tinha ainda foro académico. De certo modo, era preciso humilhá-la. Levado pela onda jacobina da sua juventude, fixada pelo bairrismo portuense (à Sampaio Bruno, à Basílio Telles, à 31 de Janeiro), Leonardo Coimbra foi a mão que desferiu o golpe. Aí se revela a ausência de institucionalismo que empequenece o pensamento político do grande filósofo. Também ele foi um dos 'filhos de um século maldito' que Antero chorava.» ${ }^{45}$

É, porém, n'A Questão Universitária que deveremos buscar as verdadeiras, todavia imediatas, razões leonardinas. Sendo embora certo que o autor aproveitará essa oração parlamentar para se justificar por ter sido «imperfeito na realização» (aludia ao decreto de 10 de Maio) ${ }^{46}$, ele teorizará aí a sua concepção sobre a Universidade num momento «crítico da história da evolução da humanidade, em que uma transmutação e criação de valores vão tornando erróneas as categorias sociais e as fórmulas políticas» ${ }^{47}$. Explicando, esse momento de «crise», pela falta de maleabilidade de uma herança que «encerra uma parte de crença, cuja evolução caminha sempre em atraso» ${ }^{48}$, a inércia adveniente dessa «força de coesão entre associações de certos estados psíquicos» que é no fim de contas a crença, provaria «a grande força conservantista da sociedade» ${ }^{49}$. Neste quadro, segundo L. Coimbra, «as Universidades são (...) grandes factores de evolução da crença.» $^{50}$

Injusta e ingenuamente, a nosso ver, embora enquadrando-se em certo espírito do tempo, o filósofo do Porto interpretava a conquista, pelos jesuítas, do Colégio das Artes, nesse quadro conservantista ${ }^{51}$. Dificilmente

${ }^{44}$ A. Ferrão, «O Prof. Joaquim de Carvalho...» 227. Para um outro «caso» universitário envolvendo o Ministro, vd. o panfleto anónimo Os perdões de acto do Sr. Leonardo Coimbra emquanto foi Ministro da Instrução Pública, Coimbra 1919.

${ }^{45}$ H.B. Ruas, «Nota Preliminar» in Leonardo Coimbra, Dispersos. V-Filosofia e Política. Compilação, fixação do Texto e notas de P. Gomes e P. Samuel, Lisboa 1994, 13.

${ }^{46}$ L.Coimbra, A Questão Universitária... 624.

${ }^{47}$ L.Coimbra, A Questão Universitária... 607.

${ }^{48}$ L.Coimbra, A Questão Universitária... 607-08.

${ }^{49}$ L.Coimbra, A Questão Universitária... 608.

${ }^{50}$ L.Coimbra, A Questão Universitária... 609. O sublinhado é do autor.

${ }^{51}$ Cf. L.Coimbra, A Questão Universitária... 609. 
poderemos dizer que Leonardo e Orlando Vitorino têm ambos razão nas justificações que nos legaram. «Jesuíta» era, como se sabe, na época, um adjectivo fácil de opróbrio político e cultural, não totalmente desprovido de razão, é certo ${ }^{52}$, mas o ponto de vista de L. Coimbra passava por ver ali uma ameaça à liberdade a qual explicará, finalmente, a alegada estranheza da Universidade perante a política do seu tempo e do seu mundo ${ }^{53}$. «A Universidade, declara formalmente o filósofo, falhou nesse momento, porque não a animava um nobre espírito de liberdade, uma lúcida compreensão humana da grande experiência de dor e amor que se ia fazendo.» ${ }^{54} \mathrm{E}$, enfim, que liberdade seria essa, a da Universidade enquanto «templo da liberdade»? Não, responde, «a faculdade de ensinar todas as doutrinas e deixar contestar todas as afirmações», o que seria «simplesmente uma caricatural inversão da verdadeira liberdade». ${ }^{55}$ Entendamo-lo bem: «É claro que todas as doutrinas se podem ensinar, mas depois de ter despertado no estudante o espírito de liberdade que the permita o passeio por entre essas doutrinas, sem que o hipnotismo o fixe de vontade adormecida em qualquer ponto brilhante do seu horizonte. A livre discussão, sim; mas tendo o aluno de amar a verdade e saber que existe a honestidade do pensamento que é o próprio fundo e alicerce do carácter moral.» 56

Havia chegado então o momento de L. Coimbra aplicar ou concretizar o seu pensamento, confrontando-o com a sua leitura da realidade: «Do corpo da nossa Universidade filtra-se, porventura, esta luz serena da liberdade, atravessando-o, iluminando o solo e as almas da nação? $\gg^{57}$ A resposta não se faz esperar. Impotente em afirmar-se perante a realidade da guerra ${ }^{58}$ - insista-se que estamos em 1919, meio ano após o desfecho Primeira Guerra Mundial - sem «voz para os grandes momentos do mundo e da pátria», «no acume da crise dos valores sociais, quando as categorias da civilização humana vão sofrer a discussão da sua vitalidade na expe-

52 Cf. J. Barata-Moura, Estudos de Filosofia Portuguesa, Lisboa 1998, 249-51 a propósito do livro de M. Bombarda, A Ciência e o Jesuitismo (1900); de modo mais lato, vd. J.E. Franco, «Génese, evolução e carácter do antijesuitismo em Portugal: uma perspectiva evolutiva», in AA.VV., O Anticlericalismo português: História e Discurso. Actas do Colóquio, Aveiro 2002, 71-93.

${ }^{53}$ L.Coimbra, A Questão Universitária ... 610: «Mas, então, uma Universidade declara-se estranha à política, que é a técnica das realizações sociais.» O itálico é do autor.

${ }^{54}$ L.Coimbra, A Questão Universitária... 610.

${ }^{55}$ L.Coimbra, A Questão Universitária... 611.

${ }^{56}$ L.Coimbra, A Questão Universitária... 611.

${ }^{57}$ L.Coimbra, A Questão Universitária... 612.

${ }^{58}$ L.Coimbra, A Questão Universitária...612. 
riência da guerra, a Universidade de Coimbra produz teses completamente niilistas. Teses em que se defende o direito da força, em que se degrada a vida superior do espírito até aos automatismos sociais, gerados pelo fanatismo no mundo das ideias e pela obediência absoluta no mundo das vontades» ${ }^{59}$. Sem nos determos naquilo que L. Coimbra, na alocução parlamentar, chamará «o meio histórico do conflito» ${ }^{60}$, importa esclarecer que o repúdio a uma certa tese coimbrã sobre «o direito da força», nem se abrigava sob a figura de F. Nietzsche, nem sob o elogio da violência, por G. Sorel, mas derivava, alegadamente, da «doutrina jesuítica» do inominado autor de tal tese. Não obstante serem «livros isolados»- precisa estranhamente o filósofo e ministro -, eles «nasceram numa atmosfera que lhes deu suficiente oxigénio para a vida. Não quero dizer, atenua agora L. Coimbra, que a Universidade é jesuítica; demonstrei que ela dormita sobre os bens espirituais da Pátria» ${ }^{61}$.

Apesar da incongruência adjectiva, o diagnóstico, nas suas palavras, «histórico», seria o de que faltava a virtude que «ilumina a fisionomia espiritual do povo português», a lealdade. Carecia também de liberdade, daquela «honestidade do pensamento que é o próprio fundo e alicerce do carácter moral». Caracterizada, a virtude da lealdade, como uma doutrina, um método e um sentimento de força e empreendimento, o ministro reconhece que «o jesuitismo e a inquisição maculam e deformam a lealdade e a audácia da alma portuguesa ${ }^{62}$. Deste complexo estado, testemunhado impressivamente por episódios civis e políticos coevos, L. Coimbra responsabilizará a Universidade de Coimbra e a sua Faculdade de Letras por dedicar «especial atenção ao elogio histórico de jesuítas...» 63 Antes de passar a justificar o modus operandi de algumas das suas decisões - no fim de contas determinadas por um «sincero e comovido amor da pátria e da república» que levou à concepção de «uma escola de Filosofia para onde a atracção da Beleza chamasse as almas incertas da gente moça do meu país» ${ }^{64}-\mathrm{L}$. Coimbra ainda observa que a sua reforma «não encontrou nenhum combate científico ou pedagógico» de relevo, pois, os que o fizeram, «ou confundem as ciências fundamentais com as derivadas, ou, citando o que não entendem, querem provar o contrário do que as citações na verdade dizem sobre o problema. Outros discutem os nomes das disciplinas, que sabem de cor, na completa inapreensão do seu

\footnotetext{
${ }^{59}$ L.Coimbra, A Questão Universitária... 616. O sublinhado é do autor.

${ }^{60}$ L.Coimbra, A Questão Universitária... 617.

${ }^{61}$ L.Coimbra, A Questão Universitária... 617; vd. também 616-17.

${ }^{62}$ Cf. L.Coimbra, A Questão Universitária... 618.

${ }^{63}$ L.Coimbra, A Questão Universitária... 622.

${ }^{64}$ L.Coimbra, A Questão Universitária... 624.
} 
significado espiritual». ${ }^{65}$ Situando, não sem ironia, mas também com definida explicação, noutro lugar, a temática da desanexação, para um plano de relações entre os organismos e os meios que lhes permitem subsistir - «a transferência duma Faculdade é uma questão de mesologia», decifra $^{66}$ - L. Coimbra, no seu jeito não apenas retórico, explica, a terminar, porque quis criar nada mais do que «o condicionalismo do sucesso»: «Eu quis hospedar na Universidade portuguesa, casa cerimoniosa e pesada, a própria alegria, para que uma manhã os velhos claustros ressoassem ressurreição e vida, revoadas de canto, como se a primavera tivesse metido pelas janelas partidas, ramos de flores, frescura, cor, alacridade...» ${ }^{67}$

Importa perguntar, então, como se concretizou essa hospedagem tão caprichosamente descrita. Ao modificar o quadro do $6^{\circ}$ Grupo, o decreto 5491 (de 2 de Maio de 1919) incluía a Matemática, a Física, a Química e a Biologia. Esta legislação será imediatamente revogada com a saída de L. Coimbra do Ministério. Ao mesmo tempo, a sua partida da pasta ministerial, permitiu que, sob proposta de 23 de Junho, publicada em 27 de Agosto (Lei 861), pelo novo ministro, Joaquim José de Oliveira, se restabelecesse a Faculdade de Letras da Universidade de Coimbra e, finalmente, a criação da sua congénere na Universidade do Porto68. Viu-se assim gorado o «primaveril projecto» de reforma curricular de L. Coimbra para as Ciências Filosóficas (vd. Apêndice II).

Que se tratava de um manifesto filosoficamente alicerçado (apesar do tom retórico, aqui e ali incoerente, e sobretudo genérico) e não exclusiva intervenção política ingénua, prova-o a insistência do autor sobre as ideias pedagógicas e mesmo sobre uma certa ideia de Universidade. Apesar de tudo será só na tese apresentada ao Congresso da Esquerda Democrática, realizado em 1926, que L. Coimbra voltará a reflectir sobre matéria educativa, de uma maneira mais apropriada a um pensador e filósofo ou, se quisermos glosar no seu sentido mais vulgar a palavra de Platão com que começámos este artigo, desprovida de mesquinhez ${ }^{69}:$ «Nenhuma nação

${ }^{65}$ L.Coimbra, A Questão Universitária... 623.

${ }^{66}$ L.Coimbra, A Questão Universitária... 624. E em O Problema da Educação (Tese apresentada ao Congresso da Esquerda Democrática realizado em 1926), Porto 1926, 44, formula a seguinte «hipótese ingénua»: «Assim, por exemplo, uma faculdade, ou escola, de técnica agrária estaria melhor em Coimbra que no Porto, como a faculdade de direito estaria melhor no Porto que em Coimbra.»

${ }^{67}$ L.Coimbra, A Questão Universitária... 624. Os sublinhados são do autor.

${ }^{68}$ R. de Carvalho, História do Ensino em Portugal: desde a fundação da nacionalidade até ao fim do regime de Salazar-Caetano, Lisboa, 1986, 690-91.

${ }^{69}$ L. Coimbra, O Problema da Educação Nacional (Tese apresentada ao Congresso da Esquerda Democrática realizado em 1926), Porto 1926, 7. 
pode viver sem cultura e as formas de cultura são todas hoje de carácter universalista: a Ciência, a Filosofia, a Arte, a Técnica, e até as Religiões». E continuava: «A finalidade meramente humana seria uma abstracção se desprezasse as realidades nacionais, porque os valores de cultura são universais em sua essência abstracta, mas nacionais em suas formas actuais de existência. Eis, portanto, o fim da educação: a cultura nacionalhumana» ${ }^{70}$. Posto que «... educar é cultivar as liberdades criadoras da cultura nacional-humana» ${ }^{71}$, defende uma educação mais voltada para 0 futuro do que para o passado ou o presente, comparando-a embora com o corredor de obstáculos, que no salto se apoia no presente, aproveita a velocidade passada e olha para o futuro ${ }^{72}$. E enfatiza, de maneira superior: «Uma educação voltada para o passado ou para o presente dará uma simples repetição da vida social de pronto mumificada num ritualismo insignificante... ${ }^{73}$

Ainda no mesmo discurso ao Congresso partidário, L. Coimbra afirma que «o Estado tem de limitar a sua acção à linha geral da cultura, não pode impor mais que um método, uma atitude que deixa às liberdades a escolha das doutrinas especulativas que melhor recebam o seu acordo» ${ }^{74}$. Passando a enunciar a «orgânica da educação», o filósofo do «criacionismo» formula a seguinte tese: «Uma Universidade é, antes de mais nada, o saber teorético, seja: faculdade de ciências de natureza, faculdade de ciências do espírito e faculdade de Filosofia.» ${ }^{75} \mathrm{E}$ explica, em termos que ainda hoje em dia nos podem tocar: "Mas o destino superior das ciências teoréticas é o desenvolvimento da cultura e a sua utilidade não deve medirse pelo seu rendimento imediato, mas pela sua produção científica, de professores e alunos, e pela sua acção social de dignificação intelectual do meio. Se amanhã não houver um estudante de filosofia em Portugal, não deixará, por isso, a filosofia de ser ainda mais necessária ao desenvolvimento do espírito cultural. (...) Este ensino é a alma da educação nacional, ele, o criador de valores, ele, o formador de profissionais, factores vivos de outro ensino.» ${ }^{76} \ll \mathrm{O}$ homem antes de ser um especialista é um homem, e só será um homem completo com as capacidades científicas, estéticas e técnicas, que definimos.» ${ }^{77}$ Estamos em crer que, neste

\footnotetext{
${ }^{70}$ L. Coimbra, O Problema... 8.

${ }^{71}$ L. Coimbra, O Problema... 9.

${ }^{72}$ Cf. L. Coimbra, O Problema... 9-10.

${ }^{73}$ L. Coimbra, O Problema... 10.

${ }^{74}$ L. Coimbra, O Problema... 36.

${ }^{75}$ L. Coimbra, $O$ Problema... 44; o itálico é do autor.

${ }^{76}$ L. Coimbra, O Problema... 46-7.

${ }^{77}$ L. Coimbra, O Problema... 50.
} 
momento, desligado das arengas e retomada a natureza filosófica que o alimentou, L. Coimbra estava finalmente mais próximo da nossa reflexão inicial.

Regressemos, no entanto, à questão universitária. Poder-se-ia, neste caso, presumir que a nomeação, sem prévia auscultação do corpo docente em exercício ${ }^{78}$, dos dois novos professores já referidos, Newton de Macedo e Lúcio dos Santos, visava justamente colmatar de algum modo aquelas deficiências e adubar o advento da «ressurreição e vida». Quanto ao advogado Lúcio dos Santos, sabemos apenas que foi professor na Universidade do Porto, deputado pelo círculo de Guimarães (1922), tendo falecido em 1950 no Rio de Janeiro ${ }^{79}$. Newton de Macedo, figura que tem sido ofuscada pela maior atenção que se tem dedicado ao seu mestre L. Coimbra, apresentara à Escola Normal Superior de Lisboa, em 1917, a dissertação A Crise Moral e a Acção Pedagógica; no próprio ano da desanexação, Aspectos do problema Psicológico; mais tarde (1933), na Imprensa da Universidade de Coimbra, As Novas Tendências da Psicologia Experimental - A Teoria da Forma, onde «concebe a ciência como construção do sujeito, sublinha as limitações do conceito positivista da ciência e recusa a redução do campo estritamente experimental, defendendo a aposta nas potencialidades criativas da via hipotético-teórica e a fecundidade gnosiológica do erro» ${ }^{80}$. Importa acrescentar já que a Faculdade de Letras da Universidade de Coimbra e o seu Grupo de Filosofia contava com um catedrático especialmente interessado na psicologia e responsável pela redacção de um manual de Filosofia, o professor e deputado Alves dos Santos.

Também numa introdução à Filosofia, analisando a designação então em voga, «filosofia científica», Newton de Macedo debruçava-se sobre o seu «justo valor» nos termos seguintes: «Designação legítima se entendermos por tal que a Filosofia não pode prescindir, no exercício da sua actividade, da base sólida que a ciência lhe faculta, sob pena de não passar duma teia emaranhada de abstracções fantasistas. Designação ilegítima se com ela se pretender reduzi-la a uma simples cópia, embora ampliada da Ciência, esquecendo a legitimidade das outras atitudes do espírito em face

${ }^{78}$ Cf. A Faculdade... (33).

${ }^{79}$ Cf. A.H.O. Marques et al. (coord.), Parlamentares e Ministros da $1^{a}$ República (1910-1926), Lisboa Porto, 2000, 392.

80 J.P.V.G. Vaz, «Macedo (Francisco Romano Newton de)» Logos. Enciclopédia LusoBrasileira de Filosofia. Vol.: 3, Lisboa 1991, 563; veja-se sobretudo D. Santos, Situação valorativa do positivismo [original de 1938], in Id., Obras Completas. I: Da Filosofia, Lisboa 1971, 51-195. 
da realidade, atitudes tão humanas, mais humanas mesmo, num certo sentido, que a atitude científica.» ${ }^{81}$

\subsection{Alves dos Santos e a filosofia positiva}

Recordemos a pergunta de Leonardo Coimbra: «Do corpo da nossa Universidade filtra-se, porventura, esta luz serena da liberdade, atravessando-o, iluminando o solo e as almas da nação?» ${ }^{82}$ Conforme lembrámos acima, e posto que se tratou de uma intromissão em Filosofia, os dois únicos docentes do $6^{\circ}$ Grupo eram, na altura da intervenção leonardina, o catedrático Augusto Joaquim Alves dos Santos (1866-1924) ${ }^{83}$ e o assistente Joaquim de Carvalho ${ }^{84}$. Como se depreende, a inclusão, por Leonardo Coimbra, das quatro disciplinas científicas e a nomeação dos dois docentes supra mencionados indiciava, segundo o Ministro, um incumprimento curricular, por parte da secção de Ciências Filosóficas da Faculdade de Letras coimbrã. Um opúsculo anónimo e circunstancial, defensor da causa dos ofendidos, apressava-se a refutar que aqueles dois docentes tivessem opiniões «escolásticas», antes cultivavam «a mais ampla liberdade criadora» dos alunos. Não estamos certos de que o refrão da liberdade, pelos dois naipes da contenda, sintonizasse numa só voz, mas não podemos dizer, sem mais, que o lado coimbrão também não tivesse uma ideia sobre o ensino universitário.

Tendo em vista «a blandiciosa e dadivosa ditadura de $1919 »^{85}$, propondo uma reforma dominada pela ideia de evolução, de «desenvolvimento, ou (...) evolução biopsíquica do ser humano, desde a recémnascença até à idade adulta» ${ }^{86}$, na sua qualidade de professor e deputado, Alves dos Santos considerava, alguns anos depois (1921), ser «tríplice a

${ }^{81}$ N. de Macedo, Introdução à Filosofia. Seu Significado e Valor, Porto 1926, 29. Relembremos, por fim, embora para um período ulterior, que ficámos a dever a Newton de Macedo a tradução do Discurso do Método e das Paixões da Alma.

${ }^{82}$ L.Coimbra, A Questão Universitária... 612.

${ }^{83}$ A Faculdade... (9) - (10); A.dos Santos, Um plano de reorganização do Ensino Público. Projecto de lei, para ser apresentado à Câmara dos Senhores Deputados, Coimbra 1921; cf. A.H.O. Marques et al. (coord.), Parlamentares... 389.

${ }^{84}$ Cf. A.F. Morujão, «Meio século de Filosofia na Faculdade de Letras de Coimbra (1945-1995), Revista Portuguesa de Filosofia 51 (1995) 244-247; J. M. dos Santos e J.M. A.e Silva, «O filósofo-historiador Joaquim de Carvalho« in Id., A Historiografia dos Descobrimentos através da correspondência entre alguns dos seus vultos, Coimbra 2004, 7-64.

${ }^{85}$ A. dos Santos, Um plano... 5.

${ }^{86}$ A. dos Santos, Um plano... 23. 
função do ensino universitário: criar ciência; transmitir a ciência feita; promover a cultura da Nação sobre as bases do luzismo ou da civilização portuguesa. Nas Faculdades de Letras e de Ciências, ensinam-se e desenvolvem-se as ciências puras da Natureza, da Vida e do Homem... ${ }^{87}$ No manual que compôs para o ensino secundário da Filosofia, A. dos Santos sintoniza com o princípio da substituição da «filosofia especulativa, de índole meramente intelectualista ou dogmática, que aspira vãmente à posse da verdade absoluta» pela «filosofia positiva ou cientista, de natureza exclusivamente fenomenal, que se contenta com a verdade relativa, pesquisada, pelo emprego dos processos do método experimental, fundada sobre as conclusões certas da ciência» ${ }^{88}$. Ao mesmo tempo que via a psicologia, a lógica e a moral a constituírem-se como «ciências independentes» e se reputava a «metafísica incompatível com o espírito filosófico», caracterizava-se este como «o pensamento da ciência» e a Filosofia como a «sistematização e a mais alta generalização das conclusões certas, a que, em todos os domínios da actividade humana, chega a ciência experimental» ${ }^{89}$. De acordo com esta última caracterização, a filosofia dividir-se-ia nos quatro domínios seguintes: filosofia matemática - estudando os problemas do número e da extensão, i.e., as propriedades quantitativas das coisas -; filosofia cosmológica - em relação às ciências físico-químicas estudaria a constituição da matéria, i.e., as suas propriedades qualitativas (organoléticas); filosofia biológica - em relação às ciências naturais, estudando o fenómeno da vida, o fenómeno da consciência, o fenómeno da conduta e o fenómeno da religiosidade -; e filosofia sociológica, que estudaria os fenómenos da sociabilidade ${ }^{90}$. O motivo do «sistema» regia, evidentemente, esta concepção, e, não menos importante ainda, a perspectiva histórica a dois tempos sobre a história da filosofia, que iniciava a «época da renovação filosófica e científica» com Bacon. Com a renúncia à metafísica, que substitui pelo raciocínio a posteriori em que se lançam os fundamentos da filosofia cientista, aquele «fundador da filosofia experimental e pai do positivismo moderno», tivera como continuadores Locke, Condillac, Hume, até que se atingiu o «máximo esplendor» com Comte. Se a este se deve o reconhecimento de uma única realidade, a dos factos, baseada sobre a observação e a experiência, ao novi-criticismo de Kant ficara-se a dever a incognoscibilidade do

${ }^{87}$ A. dos Santos, Um plano... 13 (actualizámos sempre a ortografia).

${ }^{88}$ A. dos Santos, Elementos de Filosofia Scientífica, Coimbra 1915, vi. Os sublinhados são do autor.

${ }^{89}$ A. dos Santos, Elementos... vii.

${ }^{90}$ A. dos Santos, Elementos... 22-23. 
absoluto $^{91}$. Enfim, enquanto "a ciência explica os fenómenos, a filosofia explica a própria ciência», de onde resulta que as ciências, sem a filosofia, são um agregado sem unidade, um corpo sem alma; e, pelo seu lado, a filosofia, sem as ciências, seria uma alma sem corpo, indistinta da poesia e dos sonhos.» ${ }^{92}$ Se levássemos a sério o motivo anti-positivista que justificou a intervenção do ministro Coimbra poderíamos pensar, em face do resumo feito, que Alves dos Santos - em Apêndice (III e IV) reproduzimos alguns sumários do seu ensino -, ex-teólogo e novel psicólogo, seria um alvo a atingir na $6^{\mathrm{a}}$ secção. O que se passaria com o seu assistente?

\subsection{Joaquim de Carvalho e o "espírito universitário» ${ }^{93}$}

Tal como Lúcio dos Santos também Joaquim de Carvalho - decerto hoje figura mais conhecida do que a do «apóstata» e pressuroso psicólogo Alves dos Santos - provinha do Direito ao que acrescentara uma licenciatura em Letras. Além da anónima defesa já referida, publicada em folheto, contamos com as próprias palavras de J. de Carvalho, compostas por ocasião do decreto do filósofo portuense (A Minha Resposta). Não será diferente da resposta anónima que já citámos, o tom da réplica mais circunstanciada do jovem assistente aos «dislates» e «à pérfida imbecilidade» do co-autor do Decreto, o bacharel de Direito e na sequência Reitor da Universidade, Joaquim Coelho de Carvalho, mas também à «traição» espiritual e à «obra miseravelmente sectária» de Leonardo Coimbra $^{94}$. Entre palavras certas contra o «psitacismo e o lugar-comum» que grassavam, pela sua resposta perpassa ainda a ironia ao «impressionismo e o que para aí chamam petulantemente crítica subjectiva», em parte dirigido ao estilo de Leonardo Coimbra ${ }^{95}$.

Depois de haver escrito António de Gouveia e o Aristotelismo da Renascença. António de Gouveia e Pedro Ramo (1916), J. de Carvalho defendera nova tese sobre Leão Hebreu filósofo (1918), tendo no interim leccionado História da Filosofia Antiga, História da Filosofia Moderna e Moral (1916-17) e, entre 1917-18, acrescentando às duas últimas, a regência da História Geral da Civilização (reproduzimos em Apêndice dois dos seus sumários, um deles em História da Filosofia, área em que se tornou renomado, o outro em Moral, a título de comparação com os de

\footnotetext{
${ }^{91}$ A. dos Santos, Elementos... 9.

92 A. dos Santos, Elementos... 14, 16-17.

93 As palavras do título são do próprio J. de Carvalho, A Minha Resposta 13.

94 J. de Carvalho, A Minha Resposta, 4, 6 respectivamente.

95 J. de Carvalho, A Minha Resposta 12, e 9.
} 
Alves dos Santos). Atendendo a que o autor datava a criação da História da Filosofia como disciplina autónoma, dos inícios do século XIX, e dada a sua perspectiva legitimamente crítica dessa produção, é de crer que se tivesse visto, a si próprio e ao seu trabalho histórico-filosófico, como uma inovação nacional ${ }^{96}$. Vale a pena observar que, fazendo uma rapidíssima autobiografia intelectual, depois da «meditação assídua de Kant» J. de Carvalho elege Hegel na raiz das suas investigações sobre os filósofos portugueses ${ }^{97}$.

Mas será que o jovem Joaquim de Carvalho representava, na sua secção, o tão temido «jesuitismo»? Seria injusto ver nas suas teses histórico-filosóficas qualquer resquício desse tique. Herdeiro, nesse ponto, da tradição criada por J. de Carvalho, o professor Arnaldo de Miranda Barbosa atestará, mais tarde, que o espírito que animava a prática da investigação e do ensino na Universidade era outro: «Nestes nossos dias, em que imaginações aquecidas pelo ardor dos sentimentos ou pelo prurido da originalidade procuram descobrir divinos Platões até nas mais singelas páginas das nossas letras, impõe-se o trabalho sério de investigar as raízes da nossa cultura, as formas que ela revestiu, as fontes que a alimentaram, os frutos que produziu ou inspirou. Mas um trabalho dessa natureza não

${ }^{96}$ Cf. J. de Carvalho, «Evolução da Historiografia filosófica em Portugal», in Joaquim de Carvalho. Obra Completa. Vol.: II, Lisboa 1981, 121. É claramente enviesada qualquer desvalorização da produção filosófica do autor, por sobrevalorização da sua obra historiográfica, como se esta não fosse real actividade filosófica; vejam-se, v.g., as apreciações sumárias, superficiais e contraditórias de R. Fernandes («A Filosofia de Vieira de Almeida no seu contexto ideológico» in Vieira de Almeida Obra Filosófica 1, Lisboa 1986, LXII): «Na Faculdade de Letras da Universidade de Coimbra, na Secção de Filosofia, distinguiu-se a operosa actividade de Joaquim de Carvalho (1894-1958), mais vocacionado para a historiografia filosófica do que para a produção teórica. Os pressupostos ideológicos da sua historiografia não andarão longe, porém, do idealismo neo-kantiano de Léon Brunschvicg e de Ernst Cassirer, o que explica a sua aproximação, até determinado momento, do idealismo crítico de António Sérgio. Na fase final, a sua obra é marcada por uma vincada polarização em torno do tema do 'saudosismo' e pelo seu ingresso em plena metafísica idealista. A contribuição especulativa de Joaquim de Carvalho é, por tudo isto, limitada, avultando os seus trabalhos, todavia, no plano da investigação histórico-cultural de expressão filosófica.»

97 J. de Carvalho, A Minha Resposta 6: «A vivacidade dos sentimentos levou-me a considerar conceptualmente, com Hegel, a história como o desenvolvimento do Espírito, isto é, o desenvolvimento da filosofia na história como a criação da própria filosofia. É então que começam os meus estudos de filósofos portugueses. (...) Apesar de reconhecer a pobreza da nossa herança filosófica, reputei prematuros os juízos de Bruno e Basílio Teles. Afigurava-se-me, e afigura-se-me, que o que se impõe são estudos sérios: a conclusão virá por si.» 
pode ser uma obra de apologética, senão que de serena investigação, onde mais importa descobrir pequenas certezas do que sugerir brilhantes hipóteses, se estas têm apenas a sustentá-las não a fruía nudez dos factos, mas o calor do entusiasmo, mesmo quando é despertado pelos mais louváveis e respeitáveis afectos. Deste modo, ensaios analíticos das nossas obras filosóficas, que nos ajudem a estudá-las e a compreendê-las no seu seio e no horizonte cultural da sua época, mesmo que revistam carácter provisório ou parcelar, são as pedras, as pequenas pedras que ajudarão a erguer com segurança a imagem histórica da verdadeira cultura portuguesa.» ${ }^{98}$

Voltemos ao episódio. O anónimo opúsculo A Faculdade de Letras da Universidade de Coimbra ao País negava que o ensino da filosofia em Coimbra alguma vez tivesse tido «um carácter confessional ou livresco» ${ }^{99}$. Numa breve reflexão em torno do que pretendia ser o horizonte do curso filosófico no seio das Humanidades, liam-se as seguintes palavras programáticas: «A Faculdade de Letras da Universidade de Coimbra, professando a existência de uma ciência das letras, de par que inicia os seus alunos no estudo crítico da letra e do espírito dos textos, qualquer que seja o seu conteúdo, procura igualmente despertá-los para a cultura, aspirando que, na medida das suas qualidades pessoais, uns criem, outros saibam, mas que todos trabalhem com proba austeridade. Todos os seus professores e assistentes, na sua actividade docente, têm o orgulho de só confiarem na razão, de poderem atingir verdades úteis no domínio das ciência morais e de contribuírem para a verdadeira democratização da cultura, elevando as inteligências médias, sem diminuir a élite.» ${ }^{100}$

Vale a pena continuarmos a ler a prosa anónima e justificativa em momento assaz difícil da ameaçada Faculdade; ela dá-nos a imagem que de si tinha a própria Faculdade de Letras de Coimbra: «O ensino da filosofia não teve nunca um carácter confessional ou livresco. O prof. e o assistente desta secção, quaisquer que fossem as suas opiniões - e não são escolásticas, como o provam os seus trabalhos, incutiram sempre aos alunos a mais ampla e criadora liberdade, curando mais de lhes despertar o filosofar que sugerir propriamente uma filosofia, exigindo-lhes apenas probidade intelectual. A oposição das teorias e dos sistemas era desen-

98 A.M. e Barbosa, «Prefácio» in Mª.L.C.R. de S. Coelho, A filosofia de Silvestre Pinheiro Ferreira, Braga 1958, ii-iii. Na mesma linha -repetimos - das palavras com que Joaquim de Carvalho prefaciara em 1916 o seu António de Gouveia e o Aristotelismo da Renascença (vd. a propósito J. de Carvalho, A Minha Resposta 8-9.)

${ }^{99}$ A Faculdade... 45; cf. A. Ferrão, «O Prof. Joaquim de Carvalho e a sua época» Miscelânea de Estudos a Joaquim de Carvalho 3 (1960) 213-237 [10-27-A-27-3].

${ }^{100}$ A Faculdade... 49. Actualizámos a grafia. 
volvidamente exposta, precisamente para que o aluno, apercebendo-se da relatividade e variabilidade dos problemas filosóficos e das suas soluções, atingisse com plena independência mental essa desobstrução do espírito, que é a dúvida metódica, e em vez da satisfação do saber possuísse a actividade viril do duvidar, corrigir e avançar o já sabido. Por isso a iniciação nos métodos de investigação e correcção, as leituras e comentários de textos tinham um tão grande lugar na actividade docente desta secção.»101 Após citar uma passagem do catedrático Alves dos Santos justificativa da orientação prática do seu ensino de Psicologia, o anónimo autor rematava, antes de passar a uma breve descrição dos outros cursos da secção: «Oito anos de magistério não desmentem estas palavras: nas aulas teóricas, ausência de dogmatismo e de um compêndio para o exame; nas aulas práticas, no laboratório de psicologia, demonstração e iniciação nos processos científicos. Se nem todos os trabalhos dos alunos têm valor científico, alguns há dignos de consideração, acusando um processo de ensino e o esforço de um professor.» ${ }^{102}$

O tom positivista, mas ao mesmo tempo a nota kantiana sobre o ensinável são notórias nesta apologia da secção, que queria combinar ainda o racionalismo com a hermenêutica textual e a positividade histórica num horizonte culturalista onde, aparentemente, predominariam as ciências morais e o desiderato sócio-político, nacional ou mesmo civilizacional de contribuir para a democratização da cultura. A respeito das restantes disciplinas do curso, a nota observava o seguinte. «Em lógica, nenhum formalismo, e em vez das súmulas, medievais ou modernas, os inquietantes e sugestivos problemas do conhecimento, ensinados não só como esfera particular da especulação filosófica, mas como complemento dos estudos de psicologia.

«Em Moral, dada a pequena duração do curso - vale a pena notar como esta nota parentética contrasta flagrantemente com a alegado privilégio das ciências morais -, versava-se sobretudo o problema da obrigação moral, comprazendo-se o Prof. em solicitar a actividade dos alunos para uma solução pessoal ou a adesão consciente a um sistema, patenteando-lhes o valor cultural e humano dos problemas éticos e a sua importância na democracia portuguesa, dentre outros motivos, pela separação do estado e das confissões religiosas.» ${ }^{103}$ Exemplificando, o

101 A Faculdade... 45-46.

102 A Faculdade... 46-47. O autor refere o trabalho de A. Freire de Matos sobre a Medida da atenção, por meio dos tempos de reacção (in Revista da Universidade de Coimbra 4, n. 2-3).

${ }^{103}$ A Faculdade... 47. 
anónimo redactor enumerava, como dois autores versados nas aulas práticas, Kant - cujos Fundamentos da Metafísica dos Costumes havia sido traduzido por um aluno enquanto um outro traduzira o comentário de A. Buchenau, A doutrina kantiana sobre o imperativo categórico - e J.M. Guyau ${ }^{104}$. Passando, depois, à História da Filosofia, em que o estudo da origem e evolução dos problemas era acompanhada com a preocupação de familiarizar os alunos «com os textos, considerados, não como fósseis, mas como estádios vivos do pensamento humano», explicava-se: «Na filosofia helénica, comentaram-se, em face do próprio original grego, alguns fragmentos dos ante-socráticos; e inquiriu-se da leitura e entendimento do Fédon, Apologia de Sócrates, etc., de Platão.

«Na filosofia medieval, estudaram-se em particular as origens da escolástica e as suas primeiras manifestações, comentando-se S. Justino, Orígenes, Alcuíno e Escoto Erígena; e na história da filosofia moderna, expôs-se largamente o período do renascimento, um pouco por método, muito pela ampla lição de humanidade e de actividade pessoal, que colhe quem entra no seu convívio. Última cadeira do curso filosófico, em vez de se expor o seu objecto em extensão, estudava-se de preferência um período ou um filósofo, para que os alunos aprendessem integralmente e sob todos os aspectos um sistema filosófico, e na sua intimidade colhessem uma lição viva do que é e representa para o homem a filosofia. Descartes foi, por excelência, o filósofo comentado; e do espírito de iniciativa que alguns alunos acusaram reza a tradução colectiva dos Princípios do conhecimento humano, de Berkeley.» ${ }^{105}$

\section{3.}

Importa fechar este já longo dossier sobre um episódio que J. de Carvalho - leitor de Kant - interpretou como um acto contra a libertas philosophandi que visava «tirar a liberdade de pensar e de exprimir as opiniões filosóficas ou científicas» ${ }^{106}$. Independentemente da polémica, e olhando retrospectivamente com uma mirada avalizada por um íntimo convívio com a história do nosso domínio, Francisco da Gama Caeiro caracterizará todo o ensino da Filosofia em Portugal, até à reforma de

${ }^{104}$ Recordemos que Sílvio Lima (1904-1993) escreveu um Ensaio sobre a Ética de Guyau nas suas relações com a crise moral contemporânea (1927); vd. ainda J. de Carvalho, A Minha Resposta 13.

105 A Faculdade... 48.

106 J. de Carvalho, A Minha Resposta 15, e 14. 
1957, como «positivista e ecléctico, com maior ou menor incidência...»107 e de «cunho historicizante e de cultura geral (...) desde a República» 108 O mesmo estudioso via mesmo uma linha de continuidade desde 1911 até à reforma de 1957, linha que qualificou nas quatro seguintes dimensões ${ }^{109}$ :

i) hegemonia do conhecimento do facto e, daí, o predomínio historicizante do ensino;

ii) papel formativo das disciplinas de cultura geral (aqui diz que a reforma de 1957 continua nesta linha, embora em menor grau);

iii) atenção privilegiado aos domínios da Lógica e da Psicologia (de acordo com a intenção programática do Positivismo);

iv) menor estima, ou mesmo desvalorização, dos estudos de ontologia e de metafísica e de outras correntes filosóficas contemporâneas (Filosofia da Existência, Intuicionismo, Personalismo e Fenomenologia).

Estas foram incontestavelmente quatro colunas vertebrais também do ensino na Faculdade de Letras de Coimbra e, deste ponto de vista, a reflexão (não a interferência) de Leonardo Coimbra não era desprovida de importância. Não saberíamos dizer, embora possamos presumir que sim, se o forte tom semântico da polémica coimbrã se justificava. Problema mais difícil, porém, seria o da sua justeza. De facto, enquanto filosofia, o criacionismo já havia sido apresentado em 1911 em termos programáticos assaz claros: «A filosofia, visto ter de abranger todo o real, não será um intelectualismo fossilizado, nem um pragmatismo empírico, mas o que chamo o 'criacionismo' - criação de conceitos científicos e símbolos artísticos, que, sem nunca esgotarem o real, sempre o organizam sob as mais altas aspirações do espírito.» ${ }^{110} \mathrm{E}$ um mês antes (Abril de 1911), num discurso nortenho, a imprensa destacava na sua fácil sonoridade a seguinte declaração leonardina: «A filosofia moderna será, pois, aquela que, admi-

${ }^{107}$ F. da G. Caeiro, «Miranda Barbosa...» 2.

108 F. da G. Caeiro, «Miranda Barbosa ...» 3. Nas reformas das Faculdades de Letras de 1926 - continua o historiador da nossa filosofia - os estudos filosóficos perdem autonomia (aspecto negativo realçado pelas reformas de 1929 e 1930) ao fundirem-se numa secção Ciências Histórico-Filosóficas. Consideremos, no entanto, que Vasco de MagalhãesVilhena, via no agrupamento «histórico-filosófico» uma influência do seu notável trabalho de reputação internacional (cf. H. Resende, «O Historismo como princípio metodológico do pensamento filosófico de Magalhães-Vilhena», in P. Calafate, História do Pensamento Filosófico Português, Vol. V, tomo 2, Lisboa 2000, 234).

${ }^{109}$ F. da G. Caeiro, «Miranda Barbosa...» 3.

${ }^{110}$ L. Coimbra, «Crónicas Filosóficas: o Preconceito Científico», in A Montanha, apud. M.C. Pimentel, «A filosofia criacionista de Leonardo Coimbra» in P. Calafate (dir.), História do pensamento Filosófico Português. Vol. V, Tomo 1, Lisboa 2000, 58. 
tindo a actividade criadora ou liberdade, se serve dos conceitos feitos para exaltar e erguer a vida a novas riquezas económicas, intelectuais e morais. É o que chamo o criacionismo.»111 Ora, não só as categorias de «memória inventiva» e «razão experimental» se opunham ao vício cousista ${ }^{112}$, decerto encarnado numa atmosfera "positivista», como parece que - a crermos nos juízos insuspeitos e independentes de Carlos Fiolhais e de Augusto Fitas ${ }^{113}$ - seria uma flagrante injustiça não reconhecermos todo o capital de actualizada informação científica de L. Coimbra, posto ao serviço e em diálogo fecundo com a sua indagação filosófica, autorizando$\mathrm{o}$, além do mais, a verberar consequentemente algum indelével positivismo.

Não significa isto dizer que na Faculdade de Letras de Coimbra se não fizesse filosofia. A sua matriz, positivista e histórica, analítica e hermenêutica no seu horizonte cultural, de «feição nacional» nos objectos de investigação ${ }^{114}$, mas aberta ao mundo filosófico encontrou em Joaquim de Carvalho e seu discipulato um capital de indiscutível mérito e qualidade. A ponderação desse capital permanece por fazer, «de maneira séria e rigorosa» como apreciaria dizer o mesmo professor (e nós com ele). Além do apreço filológico e do cultivo seguro da história da filosofia, a escuta criteriosa de todas as vozes filosóficas que pertencem a todas as classes só se justifica no horizonte de uma meditação e de um saber permanentemente aberto à acção tempestiva e ponderada e capaz da produção alicerçada no solo mais humano. É em tais pilares - qual «uirga geometrica» - que se deve fundar todo o ensino da Filosofia na Universidade.

Mas sem sequer estar em causa, no episódio que estivemos a seguir, qualquer «conflito legal», no sentido kantiano, a intervenção de Leonardo Coimbra, enquanto intromissão política do Estado, vinha pôr em causa a autonomia intelectual de uma Escola na definição do seu horizonte de reflexão e de concepção do trabalho científico. Certamente que não vale tudo, mas a obra de valoração é uma tarefa difícil e demorada que não se

${ }^{111}$ L. Coimbra, «Crónicas...» apud M.C. Pimentel, «A filosofia...» 59.

${ }^{112}$ Cf. J.C. Gonçalves, «Leonardo Coimbra: a Filosofia Criacionista», in AA.VV., Leonardo Coimbra. Filósofo do Real e do Ideal, Lisboa 1985, 127-144; Id., «No Cinquentenário da morte de Leonardo Coimbra. A Natureza leonardina da Razão» Revista da Faculdade de Letras [Porto] 2a s. 3 (1986) 103-123.

${ }^{113}$ Cf. C. Fiolhais, «Bergson, Coimbra e o Problema do Tempo», in AA.VV., Filosofia e Ciência na Obra de Leonardo Coimbra, Porto 1994, 79-91; Id. (coord.), Einstein entre nós. A recepção de Einstein em Portugal de 1905 a 1955, Coimbra 2005, passim; A.J.S. Fitas et al., «A filosofia da ciência no Portugal do século XX», in P. Calafate (dir.), História do pensamento... Vol V, Tomo 2, 437-445.

114 J. de Carvalho, A Minha Resposta 7. 
compadece com os tempos sem história - isto é, sem futuro e sem passado - de algumas interferências. Deste ponto de vista parecem ser acertadíssimas as seguintes palavras de J. de Carvalho: «Converter as Universidades em organismos políticos, no correntio e jornalístico sentido da palavra, sobre ser uma monstruosidade pedagógica, é um crime nacional e um atentado à razão.» ${ }^{115} \mathrm{E}$ se substituíssemos «organismos políticos» por «organismos empresariais» estas palavras continuariam a ser actuais. Claras dimensões políticas por detrás da mais nobre intenção de reforma, de criar uma «escola» no verdadeiro sentido da palavra - todavia também minada pela injustificável superficialidade e incoerência adjectiva do diagnóstico de uma análise mais comum em políticos do que em filósofos - tornam este miserável episódio um caso paradigmático do desacerto de toda a intervenção política não pensada fundamentadamente, isto é dizer, equacionada com a mais desprezível mesquinhez, aquela que, em conformidade com a sentença de Platão, se opõe à totalidade e à universalidade ${ }^{115 a}$.

\section{APÊNDICE I}

[Estatutos Pombalinos (1772) $]^{116}$

\begin{tabular}{|l|}
\hline Faculdade de Filosofia (Curso filosófico com 5 cadeiras em 4 anos) \\
\hline $1^{\circ}$ ano: Filosofia Racional e Moral (Prolegómenos Gerais da Filosofia, História da \\
Filosofia, Lógica, Metafísica e Moral) \\
$2^{\circ}$ ano: História Natural (Zoologia, Botânica, Mineralogia, História de Plínio) \\
Geometria, na Faculdade de Matemática \\
$3^{\circ}$ ano: Física Experimental \\
$4^{\circ}$ ano: Química
\end{tabular}

APÊNDICE II

[Reforma curricular de L. Coimbra]

\begin{tabular}{|l|l|}
\hline \multicolumn{1}{|c|}{ Cadeiras Anuais } & \multicolumn{1}{|c|}{ Cadeiras Semestrais } \\
\hline Matemáticas Gerais & História da Filosofia Moderna e Contem- \\
Física Geral & porânea \\
Química Geral & História da Filosofia Medieval \\
Biologia & Curso prático de História da Filosofia \\
Sociologia & (Leitura e interpretação de textos): 5 se- \\
Psicologia & mestres \\
Curso prático de Psicologia & \\
Teoria da experiência (Ciência, Arte e Moral) & \\
Metafísica & \\
História da Filosofia Antiga & \\
\hline
\end{tabular}

115 J. de Carvalho, A Minha Resposta 15.

${ }^{115 a}$ Desejo agradecer ao colega Doutor Henrique Jales Ribeiro e à licenciada Marisa das Neves Henriques.

${ }^{116}$ Cf. também R. de Carvalho, História do Ensino em Portugal... 1986, pp. 479. 


\section{APÊNDICE III}

\section{[Programa de Filosofia I] ${ }^{117}$}

- Psicologia (noção e objecto). Fenómenos Psíquicos.

- O método em psicologia.

- O método em psicologia. Psicologia Zoológica.

- O método em psicologia. Psicologia Zoológica.

- O método em psicologia. Introspecção. Psicologia dos animais.

- O método em psicologia. Experimentação. Psicofísica.

- Classificação dos fenómenos psíquicos.

- Sistema nervoso do Homem. Nervos periféricos e centros sub-corticais.

- Sistema nervoso. Cérebro e cerebelo. Reflexos.

- Classificação das sensações. (Lição dada no Instituto).

- Sensações cutâneas classificação e determinação das fontes de frio e de calor. (Lição preparada no laboratório).

- Sensações álgicas.

- Sensações sinestesias. (Lição preparada no laboratório).

- Sensações otolíticas.

- Sensações olfactivas. Psicometria do olfacto.

- Sensações gustativas. Órgãos, funções classificações.

- Sensações gustativas.

- Psicologia das sensações, modo de encontrar o limiar diferencial médio.

- Sensações visuais. Aparelho da visão. Estrutura e funcionamento dos olhos.

- Sensibilidade cromática. Diagrama das cores.

- Sensações das cores. Imagem retiniana.

- Cegos cromáticos. Tábuas do Prof. Stilling.

- Sensações auditivas.

- Imagens ou representações.

- Dinâmica das imagens. Fixação dos conhecimentos.

- Patologia da memória.

- Patologia da memória. Dismnésicas.

- Amnésias temporais.

- Amnésias periódicas (estudo destas perturbações da memória nas relações com a personalidade).

- Amnésias progressivas. A lei da negação da memória.

- Amnésias parciais. Afasia.

- Patologia da memória.

- Doenças da memória. Paramnésia.

- Inteligência. Noções gerais. Relações da inteligência com a memória.

- Relações entre o cérebro e a inteligência.

- Pensamento e cérebro. Consciência e extra consciência.

- Encerramento do curso. Consciência; extra - consciência. Eu; personalidade.

- Metodologia geral.

- Teoria do conhecimento. A verdade e o erro. Critério da verdade.

- Critério da verdade. Cepticismo e Idealismo.

- Critério da verdade. (conclusão).

${ }^{117}$ Sumários da cadeira de Filosofia $1^{\circ}$ ano (ano lectivo 1913-14) do Doutor Augusto Joaquim Alves dos Santos. Este professor regia, na altura do episódio, os cursos de Psicologia, Lógica, História da Filosofia Antiga, História da Filosofia Medieval, e a cadeira de História Moderna e Contemporânea (vd. A Faculdade de Letras... 10). 


\section{APÊNDICE IV}

[Programas de Moral $]^{118}$

\begin{tabular}{|c|c|c|}
\hline$A$ & $B$ & $C$ \\
\hline $\begin{array}{l}\text { - Noção e objecto da moral } \\
\text { - Moral teórica e moral prá- } \\
\text { tica } \\
\text { - Postulados da moral } \\
\text { - Classificação dos sistemas } \\
\text { de moral } \\
\text { - Moral da religião natural: } \\
\text { fundamentos } \\
\text { - Moral de Kant } \\
\text { - Moral do prazer } \\
\text { - Epicurismo (antigo e mo- } \\
\text { derno) } \\
\text { - Moral da simpatia } \\
\text { - Moral da simpatia e mo- } \\
\text { ral da honra } \\
\text { - A moral da honra } \\
\text { - Moral solidarista } \\
\text { - Sistemas de moral } \\
\text { - Solidarismo } \\
\text { - Utilitarismo }\end{array}$ & $\begin{array}{l}\text { - Noção e objecto da moral } \\
\text { - Crítica dos "postulados } \\
\text { da moral" } \\
\text { - Os postulados da moral } \\
\text { - Sistemas de moral (clas- } \\
\text { sificação) } \\
\text { - Moral de Religião natu- } \\
\text { ral e moral das religiões } \\
\text { positivas } \\
\text { - A moral da imanência e a } \\
\text { moral da transcendência } \\
\text { - A moral da imanência: } \\
\text { o formalismo kantiano } \\
\text { - Kant: o formalismo } \\
\text { - A moral kantiana } \\
\text { - Moral do prazer } \\
\text { - O solidarismo }\end{array}$ & $\begin{array}{l}\text { - Objecto da ética } \\
\text { - A ética como ciência nor- } \\
\text { mativa } \\
\text { - Os métodos da ética } \\
\text { - Evolução das concepções } \\
\text { éticas: a concepção ho- } \\
\text { mérica } \\
\text { - Ética pré-socrática: pita- } \\
\text { góricos e atomistas e so- } \\
\text { fistas } \\
\text { - Sócrates } \\
\text { - Ética platónica } \\
\text { - Ética aristotélica } \\
\text { - Moral epicurista } \\
\text { - Moral estóica } \\
\text { - Moral cristã } \\
\text { - Moral de Kant }\end{array}$ \\
\hline
\end{tabular}

\section{APÊNDICE V}

\section{[O ensino da História da Filosofia Moderna: o Renascimento] ${ }^{119}$}

- A filosofia no Renascimento.

- O humanismo: conceitos, causas e tendências.

- Causas da decadência do humanismo e suas consequências.

- O platonismo na Itália.

- Platonismo.

- $\mathrm{O}$ aristotelismo e suas formas no Renascimento.

- O naturalismo empírico do Renascimento: Vinci e Telésio.

- O naturalismo panteísta: Giordano Bruno.

- A filosofia política durante o Renascimento.

- O cepticismo no Renascimento.

- O cepticismo na Renascimento: Francisco Sanchez.

- O cepticismo de F. Sanchez.

118 Sumários (A) da cadeira de Moral (ano lectivo 1913-14) do Doutor Augusto Joaquim Alves dos Santos. Sumários (B) da mesma cadeira (ano lectivo 1917-18) e do mesmo professor, ano em que também leccionou Filosofia I, História da Filosofia Antiga e História da Filosofia Medieval; Sumários (C) da cadeira de Moral (ano lectivo 1918-19) do Doutor Joaquim de Carvalho.

${ }^{119}$ Sumários da cadeira de História da Filosofia Moderna (ano lectivo 1918-19) do Doutor Joaquim de Carvalho. Nomeado assistente provisório em 1916-17, Joaquim de Carvalho dirige as aulas práticas de História da Filosofia Antiga, História da Filosofia Moderna (desde 1917-18 assumiu a regência teórico-prática deste curso) e Moral; desde 1919 assumiu a cadeira de História Geral da Civilização (vd. A Faculdade ... 23). 